\title{
Communication Skills Used by English Major Graduates in the Workplace: A Case Study
}

\author{
Pornpan Chairat
}

\begin{abstract}
This study aims to explore English communication skills used by English major graduates in the workplace. The respondents consist of 65 English major graduates who obtained bachelor's degree in English at a university Thailand in the academic year 2012. The data were collected from the questionnaire with open-ended questions. Based on the results, it is apparent that all types of workplace communication skills are performed by the participants in their current jobs and positions. In this regard, the most top three skills used according to the collected data are general English conversation, telephone and business writing (e.g. emails, faxes, memos, and letters). From these, it can be implied that the designs of the relevant courses' contents (e.g. business English, business communication, business correspondence, presentation and discussion), assignments, classroom and extracurricular activities provided for the current students at the certain university should be focused more on practicing both oral and written communication skills particularly on specific tasks as recommended by the informants.
\end{abstract}

Index Terms-Business English, communication skill, professional communication skills, workplace communication skill.

\section{INTRODUCTION}

In today's highly competitive business environment, preparing students to be ready for the future career in the dynamic labor market is considered as one of all universities' significant tasks. In other words, in order for the students to win the competition in graduate jobs, they need to be prepared and trained well by the academic institutions, especially in the rise of the mass higher education (HE) and the growth of regional economic communities and international economic organizations. To support the earlier mentioned, a recent report from UNESCO, as in [1], reveals that "employers want students to be trained according to the needs of the workplace and want to do away with subjects that are irrelevant to the needs of the working world and academics also agree that some changes are needed but emphasize these changes must balance the demands from industry against the needs of civil society and social development". In the meantime, Tan and French-Arnold also hilights that "higher education is increasingly being viewed as central to national strategies for securing shares in the global market and universities as the repositories of valuable human capital to support national development" [2].

In reality, on the contrary, the professional competence of

Manuscript received February 9, 2016; revised March 16, 2016. This work was supported in part by Western languages Department, Faculty of Humanities and Social Sciences, Thaksin University.

Pornpan Chairat is with Thaksin University, Thailand (e-mail: pornpan.ch@gmail.com). newly hired graduates is reviewed in the light according to the employers, even though it is set as the main criterion of the quality of education [3]. With above mentioned, and as much as everyone's concerned, a large numbers of research and studies conducted lately have focused more on employability and professional competence of the graduates (such as critical, problem-solving, leadership and teamwork skills) rather than communication skills in English needed and used in the real workplace [4].

However, in order to prepare English major graduates for the future career particularly those who are not native English speakers, the above idea seems to be unfit. It is somewhat predicable that their career choices once complete the degree will most likely involve using English language. Due to this reason, it is undeniable that English communication skills of the said graduates are important and highly expected by businesses and organizations.

As a result, only professional competence and employability skills are probably not enough for the universities or academic instructions to put emphasis on. To enhance English major graduates' competencies and abilities to meet the labor market's expectation and requirement, apart from professional competence and employability skills, workplace communication skills in English should also be highlighted and taught by the academic organizations.

As pointed out by Signh, Khaun \& Lan "once graduates are adequately equipped with the language skills, they will be able to perform well in their respective job tasks. As such, language programs offered in universities have to be designed to include adequate practice in reading, speaking, listening, and writing skills. These skills are equally important and are normally practiced by students in different combinations or all at the same time" [5]. The same researchers also added that "effort should be made to ensure what is taught in the course is related to authentic office situations in order to ensure that the students' professional communication skills are practiced according to the requirement of employers, and match the real workplace situations [5]."

But, by doing so, the relevant courses' instructors might end up with questions like: Where should I start?, how would I suppose to know - which areas of workplace communication to be used and required by English major graduates when performing the tasks in various organizations? This study, therefore, aims to explore the communication skills in English language utilized by English major graduates who obtained bachelor's degree from Thaksin University in the workplace. It is hoped that the study outcomes will be beneficial for relevant courses' instructors at the certain university in developing the curriculum and /or concerned courses' contents according to the graduates' feedback as well as the real requirement of the employers in the labor market. 


\section{LITERATURE REVIEW}

Scottish Qualifications Authorities summarized that "Communication skills underpin almost all personal, social, learning, and working activity. They are essential in clarifying your thoughts, in interacting and conversing effectively with others, and in conveying information, feelings, and opinions [6]. In addition, Morreale, Osboni \& Pearson also assert "as individuals mature and become working adults, communication competence continues to be essential. Communication skills are required in most occupations. Employers identify communication as one of the basic competencies every graduate should have, asserting that the ability to communicate is valuable for obtaining employment and maintaining successful job performance. The communication skills essential in the workplace include basic oral and writing skills, and the ability to communicate in work groups and teams with persons of diverse background, and when engaged in problem solving and conflict management [7]."

\section{A. Workplace Communication Skills}

Martin-Young points out that the three following skills: teamwork, flexibility, and communication are crucial for all workers as well as highlighted by employers. It is also argued that "even written and oral communication skills are very important in today's high-powered workplace, employees must also be able to use modern technology to communicate" [8]. Furthermore, technologies, such as voice mail, E-mail, fax, and word processing are proposed as the most often used in the workplace.

Guffey and Loewy, in the meantime, highlight that that communication skills are essential for career success. In addition, communication skills often ranked as the most wanted competencies among all requested by the employers in making hiring decisions. Besides, a numbers of surveys indicated that communication skills are essential for effective job placement, performance, career advancement, and organization success [9].

\section{B. Types of Communication Skills}

According to McFarlin "Understanding the types of communication skills and competencies is a vital skill both for managers and business owners as well as employees. Interacting with others is a large portion of many industries and having the necessary skills and competencies to interact with others is essential no matter what business you are in [10]."

\section{Three Types of Communication Skills in Workplace}

1) Written Communication: includes letters, emails, memos, intranet articles, meeting minutes and using social media. It can also include using graphs, pictures, posters and PowerPoint presentations.

2) Oral Communication: is used frequently throughout working day, including speaking to colleagues and members of the public, attending conferences and meetings, delivering presentations and having telephone conversations. This form of communication is more likely to be appropriate for such times as getting information from victims, witnesses or offenders; speaking with community groups; giving evidencein court; or liaising with colleagues and member of the public.

3) Non Verbal Communication: include body language, posture, eye contact and even how to dress.

\section{A Review of Related Studies}

Crosling and Ward [11] first studied needs and uses of oral communication in the workplace in 2002. The sample of this study was the business graduate employees. The study considered the development and assessment of oral communication skills in an undergraduate business and commerce curriculum. The survey results revealed that only formal presentation practiced and experienced by the undergraduates at the university is insufficient for performing oral communication in the workplace. Moreover, the outcomes also indicated that even formal presentation is required to be performed by the graduates, most of oral communication in the workplace is informal.

Later, Kassim and Ali [12] conducted the research regarding the employers' views on graduates' English communicative events and skills needed at the workplace was carried out in the next eight years. The self-developed questionnaires were distributed to the engineers of 10 multinational chemical companies in Malaysia. The findings showed that rather than written communication skills, the universities should put more emphasis on oral communication. Besides, the results of the study also revealed that teleconferencing, networking for contacts and advice, and presenting new ideas and alternative strategies are considered as important communicative events according to those engineers. In the mean time, it subjects also agreed that English language fluency is vital for them for career advancement, especially in the global stage. Finally, the study suggested that the design and development of courses' modules should be directed to the integration of workplace settings/scenarios as the basis activities.

What is more, a year later, Stevens [13] conducted the study entitled "What communication skills do employers want? Silicon Valley recruiters respond". The purpose of this study was to analyze the satisfaction levels of Silicon Valley employers with the communication skills of newly hired graduates. Based on the results, and according to the employers, both oral and written communication skills were needed to be improved in several areas, including the use of vocabulary and self-expression. The study also revealed that college students needed to be trained more on writing skills as well as professional skills such as uses of e-mail, self-expression, and avoidance of slang. The study concluded that the skills of newly hired college graduates are somewhat not sufficient for them to perform the tasks in the workplace.

In 2012, the study on oral communication skills performed by ESP Jordanian business graduate employees in the workplace was carried out [14]. It is aimed to explore the diverse forms of English oral communication among the ESP Jordanian business graduate employees working in various businesses' settings. The major tool to collect the quantitative data was the 5 point scales survey questionnaire, which was later distributed to the employers of the Isra University's graduates with bachelor's degree in business. The returned questionnaires from 24 companies were analyzed using SPSS. 
The findings demonstrated that the said graduates needed to improve their oral communication in various ranges and settings. It is also recommended that the oral communication activities should be focused and embedded in the curriculum.

Later, in the same year, the study on needs analysis of college business English course was conducted [15]. This study is aim at providing insights into the college business English learners' needs including target situation needs, learning situation needs and present situation needs.

Questionnaires, coupled with interviewed are the study's major tool for data collection. The participants were divided into three group: employers, college graduates who have more than one-year work experience in Business English, and learners of college Business English courses. Based on the results of the survey, it is suggested that college business English course should mainly focus on enhancing learners' business English listening and speaking. Furthermore, pre-course needs analysis, during-course and post-course needs analysis should also be taken on to assess learners' progress and teaching efficiency.

As mentioned above, it is obvious that previous research concerned with workplace communication skills conducted by numerous researchers for different purposes. However, none of them focused on English major graduates' needs and use of business or workplace communication skills. This study, therefore, aims to examine the workplace communication skills utilized by English major graduates. In addition, while various research approaches applied to conduct the above studies, the present study designed using questionnaire with open-ended questions adapted from $\mathrm{Wu}$ (2012) as a major tool to collect the quantitative data.

\section{PARTICIPANTS}

\section{A. Participants}

65 graduates who completed bachelor's degree in English from the Faculty of Humanities and Social Sciences, Thanksin Univeristy, Songkhla Campus in academic year 2012, and attended the commencement rehearsal for the graduation ceremony at the university during September, 20-21 2013.

\section{B. Instrument}

The major tool used in order to collect the data is the questionnaires with structured interview questions adapted from $\mathrm{Wu}$ (2012). To cover all criteria aimed to investigated, the questionnaire is divided into three sections:

Part 1: General information about the subjects which focuses on general background of the participants such as name, student identification number, current address, and employment status.

Part 2: The results on workplace communication skills required by the subjects for their careers: The questionnaire in this section was developed and monitored based on the professional communication skills utilized by the participants in the workplace.

Part 3: The results on the subjects' suggestions and recommendations for future courses development. The structured interview questions in the last section of the questionnaire were designed to reveal the informants' implications for course and/are curriculum development.

\section{Data Collection}

In order to collect the quantitative data, the 65 copies of developed questionnaires (Thai version) were distributed to the participants during the two days of their commencement rehearsal for the graduation ceremony at Thaksin University (September, 20- 21 2013).

\section{Data Analysis}

To accomplish the objective of the study, the returned questionnaires were calculated and analyzed as follows: First, to answer the general information about the subjects as well as their employment prospect and status, the frequency and percentage were used to present the main data (Part 1 and 3), and finally, the suggestions and recommendations for course development reported through the questionnaires were listed and revealed to present the main data (Part 3).

\section{RESUlts}

Part 1: General information about the subjects

The subjects in this study were 65 English major graduates who hold Bachelor of Arts in English from Thaksin University, Songkhla Campus. Most of the subjects (87.7\%) are employed by companies or organizations while the rest of them are now studying for master's degree (1.54\%), self-employed $(6.15 \%)$, and un-employed $(4.62 \%)$ as shown in Table I:

TABLE I: THE SUBJECTS’ EMPLOYMENT STATUS

\begin{tabular}{ccc}
\multicolumn{2}{c}{ TABLE I: THE SUBJECTS’ EMPLOYMENT STATUS } & \\
\hline $\begin{array}{ccc}\text { Employment status } \\
\text { Employed }\end{array}$ & Frequency & Percentage \\
Studying & 57 & 87.7 \\
Self-employed & 1 & 1.5 \\
Un-employed & 4 & 6.2 \\
Total & 3 & 4.6 \\
\hline
\end{tabular}

Part 2: The results on career types that the graduates entered after graduation and workplace communication skills required at the workplace

TABLE II: THE CAREER TYPES ENTERED By ENGLISH MAJOR GRADUATES Frequency Percentage

\begin{tabular}{lrr}
\hline Career types & & \\
Journalist & 1 & 1.75 \\
Waiter/Waitress & 4 & 7.02 \\
Receptionist & 8 & 14.04 \\
Guest Service Agent (Hotel) & 10 & 17.54 \\
Passenger Service Agent (Airline) & 8 & 14.04 \\
Sales \& Marketing & 6 & 10.53 \\
Teacher (English subject) & 11 & 19.30 \\
Other & 9 & 15.79 \\
\hline Total & $\mathbf{5 7}$ & $\mathbf{1 0 0 . 0 0}$
\end{tabular}


Table II reveals findings on the career types that the informants enter after graduation.

As illustrated in Table II, it is quite surprising that most of the subjects' work as English teachers (19.30\%), while only one of them $(1.75 \%)$ work as a journalist. The second rank career entered by the participants is 'guest service agent' $(17.45 \%)$, followed by 'receptionist' and 'passenger service agent' $(14.04 \%)$. While nine of the subjects' current jobs are not relevant to the above categories $(15.79 \%)$, six of them currently work in sales \& marketing $(10.53 \%)$. Moreover, as presented in the table, the second lowest rank career entered by English major graduates is waiter/waitress with only $7.02 \%$

TABLE III: THE COMMUNICATION SKILLS USED IN THE WORKPLACE

\begin{tabular}{lcr}
\hline Workplace Communication Skills & Frequency & Percentage \\
\hline Telephone English & 35 & 61.40 \\
Business English negotiation & 19 & 33.33 \\
Products presentation & 14 & 24.56 \\
Meeting & 10 & 17.54 \\
Business English conversation & 13 & 22.81 \\
General English conversation & 40 & 70.18 \\
Business writing (e.g. letters, faxes, e-mails, & & \\
memos, reports) & 22 & 38.60 \\
Business English reading & 17 & 29.82 \\
Business English translation & 17 & 29.82 \\
\hline
\end{tabular}

As demonstrated in Table III, 'general English conversation', and 'telephone English' are the two workplace communication skills mostly performed by over half of the subjects in their current jobs with $70.18 \%$ and $61.40 \%$ respectively. The third ranked $(38.60 \%)$ is 'business writing skill', and followed by 'business English negotiation skill' with $33.33 \%$. Moreover, seven persons (29.82\%) reported that they also require business reading and translation skills in order to perform their jobs. On the other than, products presentation and business conversation skills are regarded as the least required workplace communication skills $(24.56 \%$, and $22.81 \%$ ) according to the participants.

Part 3: The Suggestions/ Recommendations for Course Development

Q1. Based on the curriculum that you have completed, which subjects or area of knowledge do you think should be added in it in order to help prepare the current and future students for future career.

In response to the above question, the feedback from the subjects/knowledge was listed as following:

- English for airline staff/ business

- English for journalist

- English for logistics and transportations

- English for mass communication

- English conversation for daily life

Q2. Suggestions/ recommendations on the curriculum and/or major

Following are the graduates' responses to the above question:
TOEIC score (minimum 550) should be included as the university requirement for all English major students in order to complete the bachelor's degree.

In conclusion, the findings reveal that after graduation, the majority of English major graduates were employed by various types of organizations and industries where English language is used for both internal and external communication.

Furthermore, the outcomes also show that both oral and written communication skills are required to perform in by the subjects in their all current jobs, especially general English conversation, telephone in English, as well as business writing skills.

In addition to the above, while the graduates show positive feedback regarding the current courses offered in the university, they also proposed some useful courses to the existing program to help enhance and prepare the current and future students' communication skills for the real workplace situations.

\section{CONCLUSION AND RECOMMENDATIONS}

The purpose of this study is to examine workplace communication skills used by English major gradates (academic year 2012) from Thaksin Universty, Songkhla Campus for their careers after graduation. The outcomes of the study can be used for courses/ curriculum adjustment in order to prepare the current and future undergraduate students in the certain university for future careers. The method applied in this study is self-developed questionnaire with open-ended questions. The study was conducted on a sample of 65 English major graduates in academic year 2012 who attended the commencement rehearsal at the university during 20 - 21 September 2013. All participants completed and returned the questionnaires during the mentioned period.

1) What types of careers/ businesses do the English major graduates enter?

Previous study conducted by Brennen, William \& Blasko comfirms that English degree graduates "spread over a broad range of types of employment and carry out a large number of activities" [16]. As a result, "they tend to take up jobs where an English degree is not prerequisite and graduates from any discipline can apply" [16]. Likewise what stated above, it is not surprising at all that the outcomes of the present study reveal that most of the English major graduates are employed by various types of companies/ organizations where English is used as one of corporate languages. According to the obtained data, there are eight career types that the participants hold after completed the bachelor's degree: journalist; waiter/waitress; receptionist; guest service agent (hotel); passenger service agent (airline); sales and marketing; and teacher of English subject

2) What types of workplace communication skills do the English major graduates used in their current jobs/positions?

From the results, it is clear that both types of workplace communication skills (oral and written communication) are applied by the participants in their current jobs and positions. To be more specific, the most top three performed skills, 
based on the result, are general English conversation, telephone and business writing (e.g. emails, faxes, memos, and letters). Moreover, while business English negotiation, business English reading, and translation skills are required in order to complete the tasks, the findings also show that the subjects need to attend the meeting as well as give products' presentation using English language.

As stressed by Johnson, Veitch \& Dewiyanti, "communication skills needed to be taught and learned within meaningful context of discipline-based learning in order to accommodate particular disciplinary priorities and students needs [17]". Hence, it can be concluded that in order to embed workplace communication skills in the course curricular, the designs of classroom activities and assignments of the relevant courses (e.g. business English, business communication, business correspondence, presentation and discussion, etc.) provided for the current students at the certain university should be focused more on correspondence, presentation and discussion, etc.) provided for the current students at the certain university should be focused more on practicing both oral and written communication skills particularly on specific tasks/ topics as pointed out by the respondents.

3) What are the suggestions/recommendations proposed by

the English graduates for further courses and/or curriculum development?

The participants suggested that the following courses: English for airline staff/ business; English for journalist; English for logistics and transportations; English for mass communication; and English conversation for daily life should be included in the curriculum in order to prepare the students to get ready for the real workplace. The newly hired graduates also proposed adding TOEIC score (550) as the university' standard graduation requirement specifically for English major. This means, in order for the English major undergraduates to complete the bachelor's of Arts degree, they also need to present their TOEIC score (at least 550) to the university's registrar apart from the university's current requirement.

According to the researcher, the above suggestions and recommendations help confirm that workplace communication skills is seen and considered as one of the critical skills required by the English major graduates in order to perform the tasks/activities effectively in the workplace.

Due to this revelation, it is recommended that the concerned parties, especially the western languages department at the certain university should review and re-design the curriculum by adding the above suggested courses in the future. Moreover, to promote the awareness of the importance of English communication skills in the modern workplace among the current English major students, the university should take those graduates' suggestion on TOEIC score as the new graduation requirement into consideration.

4) Implications for Further Courses/Curriculum

The outcomes of the study indicated that every single type of career/position involved using English language and entered by English major graduates requires both oral and written communication skills.

Therefore, the courses concerned with English for specific purposes such as English for airline business, English for journalist, English for logistics, etc are recommended to be added in the current curriculum/program. Moreover, relevant courses' instructors should design above mentioned courses' contents by putting emphasis on practicing the real workplace spoken and written skills and situations in order to prepare the students for future career development and success in various types of businesses/organizations.

To link the above mentioned, Bhattacharyya, Nordin \& Salleh also proposed that "a graduate's ability to communicate effectively can greatly affect their career development in the future workplace. Communication lecturers need to be equipped with the knowledge of the communicative needs of their students' future working environment [18]".

In addition to this, in order to raise the awareness of English communication skills required in the workplace, the result of TOEIC score with minimum 550 is also recommended adding as the graduation requirement for the current and future English major students to present to the university's registrar office during the process of graduation request.

Taking the earlier suggestion into consideration, Gilfert also pointed out that "TOEIC scores are increasingly being required by corporate employers of either entering employees or of employees who are being considered for promotion and/or overseas assignments. Employers use TOEIC scores as a screening device, hiring only those who meet a certain pre-determined TOEIC score. Consequently, most universities and academic institutions offer TOEIC preparation for their students for many years now" [19].

5) Recommendations for Further Studies

1. Workplace communication skills are more noteworthy and reliable if an in-dept interview in employed in the methodology.

2. The needs of workplace communication skills by English major graduates is recommended to be conducted further with the emphasis on various form communication skills: non-verbal, oral, and written communication.

3. The problems caused by the lack of workplace communication skills should be studied and mentioned in the further studies.

4. It is also recommended that the employers' perceptions of English major graduates' workplace communication skills to be carried out.

\section{REFERENCES}

[1] Y. Sharma. (Feb. 2014). Rising unemployment - Are there too many graduates? University World News. [Online]. Available: http://www.universityworldnews.com/article.php?story=2014021315 3927383

[2] L. C. Tan and E. French-Arnold, "Employability of graduates in Asia: an overview of case studies," Graduate Employability in Asia, Asia and Pacific Regional Bureau for Education, UNESCO Bangkok, 2012.

[3] D. Vasilevska and G. Tatyana, "The analysis of competitiveness of University Graduates in the labor market: The case of Latvia,' Advances in Economics and Business, vol. 2, no. 1, pp. 37-41, 2014.

[4] I. Sarudin, M. N. Zainab, A. M. Zubairi, T. B. T. Ahmad, and M. S Nordin, "Needs assessment of workplace English and Malaysian graduates' English language competency," World Applied Sciences Journal, vol. 21, pp. 88-94, 2013. 
[5] P. Singh, A. Khaun, and C. Lan, "Employer expectation of language in the workplace," Malaysian Journal of ELT Research, vol. 7, no. 2, pp. 82-103, 2011.

[6] Scottish Qualifications Authority. (2013). Core skills framework: An introduction communication. [Online]. Available: http://www.sqa.org.uk/files_ccc/CommunicationCoreSkillsFramewor $\mathrm{kV} 1$

[7] S. P. Morreale, M. M. Osboni, and C. J. Pearson, "Why communication is important: A rationale for the centrality of the study of communication," Journal of the Association for Communication Administration, vol. 29, pp. 1-25, 2000.

[8] N. Martin-Young. (March 1996). Communication skills in the workplace employers talk back. CEI. [Online]. Available: http://www.sandhills.edu/academic-departments/english/teaching/co m skills.html

[9] M. E. Guffey and D. Loewy, Business Communication: Process and product, Cengage Learning, 2010.

[10] K. McFarlin. (2007). The types of communication skills and competencies. HEARST Newspaper. [Online]. Available: http://smallbusiness.chron.com/types-communication-skills-compete n cies-10651.html

[11] G. Crosling and I. Ward, "Oral communication: The workplace needs and uses of business graduate employees," English for Specific Purposes, vol. 21, no. 1, pp. 41-57, 2002.

[12] H. Kassim and F. Ali, "English communicative events and skills needed at the workplace: Feedback from the industry," English for Specific Purposes, vol. 29, no. 3, pp. 168-182.

[13] B. Stevens, "What communication skills do employers want? Silicon Valley recruiters respond," Journal of Employment Counseling, vol. 42, no. 1, pp. 12-9, 2011
[14] S. Freihat and K. Al-Machzoomi, "The picture of workplace oral communication skills for ESP Jordanian business graduate employees," International Journal of Business, Humanities and Technology, vol. 2, no. 1, pp. 159-173, 2011.

[15] Y. Wu, "The empirical study on needs analysis of college business English course," International Education Studies, vol. 5, no. 2, pp 216-221, 2012.

[16] S. Johnson, S. Veitch, and S. Dewiyanti, "A framework to embed communication skills across the curriculum: A design-based research approach," Journal of University Teaching \& Learning Practice, vol. 12, no. 4, pp. 1-13, 2015.

[17] J. Brennen, R. Williams, and Z. Blasko, The English Degree \& Graduate Careers, London: University of London, 2003.

[18] E. Bhattacharyya, M. Bt. Nordin, and S, Salleh, "Internship students' workplace communication skills: Workplace practices and University preparation," in Proc. Conference for Industry and Education Collaboration American Society for Engineering Education, 2009, pp. 1-19.

[19] S. Gilfert, "A review of TOEIC," The Internet TESL Journal, vol. 2, no. 8, 1996.

Pornpan Chairat was born on in Songkhla, Thailand, on September 27, 1982. She is a full-time lecturer in the Western Languages Department, Faculty of Humanities and Social Sciences, Thaksin University, Thailand.

Her research papers have been presented in local and international conferences. Her research interests include English for specific purposes, communication skills, professional communication, and workplace communication. 